\title{
How sustainable entrepreneurs engage in institutional change: insights from biomass torrefaction in the Netherlands
}

\author{
Neil A. Thompson ${ }^{\text {b, }}$, Andrea M. Herrmann ${ }^{\text {a }}$, Marko P. Hekkert ${ }^{\mathrm{a}}$ \\ a Department of Innovation, Environmental and Energy Sciences, Utrecht University, The Netherlands \\ ${ }^{\mathrm{b}}$ Department of Management and Organization, VU University, Amsterdam, The Netherlands
}

\section{A R T I C L E I N F O}

Article history:

Received 16 September 2013

Received in revised form

5 August 2014

Accepted 5 August 2014

Available online $\mathrm{xxx}$

\section{Keywords:}

Sustainable entrepreneurship

Torrefaction

Collaborative action

Institutional change

Biomass

\begin{abstract}
A B S T R A C T
Sustainable entrepreneurship often requires a purposeful change to the existing business environment, market regulations, and societal norms and values (institutions) to ensure sustainable products and services become legitimate and competitive. Yet, how sustainable entrepreneurs alter or create institutions remains unclear. We employ a two-year comparative case study with four entrepreneurs commercializing torrefied biomass in the Netherlands. Consistent with insights from institutional entrepreneurship research, findings show that sustainable entrepreneurs create new symbols, theorize, construct new measures, build consensus, and forge new relations to alter or create new institutions. Moreover, we find that entrepreneurial collaboration, in the form of a trade association, has three feedback effects: it creates accessible modes; diversity of scope; and an increased scale of institutional change strategies. We conclude that future studies should further connect sustainable and institutional entrepreneurship research, and take group and individual factors into account when explaining how sustainable entrepreneurs engage in institutional change.
\end{abstract}

(c) 2014 Elsevier Ltd. All rights reserved.

\section{Introduction}

Sustainable entrepreneurs aim to introduce environmentally and socially friendly innovations to a large group of stakeholders (Dean and McMullen, 2007). However, to be successful, sustainable entrepreneurs are often required to purposefully change the existing business environment, market regulations and societal norms and values (institutions). In other words, sustainable entrepreneurs may actively modify markets and institutions towards a more pro-environmental condition that allows for sustainable products to become more competitive and legitimate (Shepherd and Patzelt, 2011). In fact, sustainable entrepreneurship has recently been defined in terms of creating economic and societal value through environmentally or socially beneficial institutional innovations (Schaltegger and Wagner, 2011).

Nevertheless, changing or creating institutions is no easy feat. Institutions are, by definition, entrenched and supported through a coherent and ordered social system (DiMaggio and Powell, 1983). How resource and power scarce sustainable entrepreneurs alter or create new institutions remains unclear. Despite research

\footnotetext{
* Corresponding author.

E-mail address: n.a.thompson@vu.nl (N.A. Thompson).
}

underlining the role sustainable entrepreneurship may have for institutional change (Woolthuis et al., 2013), there currently exists little research that explains how sustainable entrepreneurs might initiate this change (Hall et al., 2010; Thompson et al., 2011). This omission has left us with room to expand our understanding of how sustainable entrepreneurs may attempt to induce institutional reform. Accordingly, we ask: How do sustainable entrepreneurs alter or create institutions?

This article employs a two-year comparative multi-case study in the emerging Dutch torrefaction industry in order to expose and clarify sustainable entrepreneurs' strategies for institutional change. The findings from this study have three main contributions to literature on sustainable entrepreneurship. First, this study demonstrates the institutional change strategies enacted by sustainable entrepreneurs as they work to alter and create institutions. While our findings are largely consistent with insights from institutional entrepreneurship research, this adds to sustainable entrepreneurship literature by verifying results from our theorybuilding case study with literature from another related area, which makes our results more valid and generalizable. Second, we uniquely propose that institutional change strategies vary between small groups and individual sustainable entrepreneurs in terms of mode, scope, and scale, and that these differences are largely driven by the rules developed to govern collaborative action. Third, we 
Table 1

Overview of institutional change strategies.

\begin{tabular}{|c|c|c|}
\hline Institutional change strategy & Brief explanation & Example from literature \\
\hline Creating new symbols & $\begin{array}{l}\text { Creating new symbols that help to re-shape and share new } \\
\text { ideas and initiate collective sense making }\end{array}$ & $\begin{array}{l}\text { Actors who represented different groups in the Israeli high-tech sector } \\
\text { engaged in constructing a shared narratives and symbols of the dot-com } \\
\text { crisis that aimed to both maintain and call for changes in the } \\
\text { institutional order (Zilber, 2007). }\end{array}$ \\
\hline Constructing new measures & $\begin{array}{l}\text { Quantifying as a way to provide measures that } \\
\text { communicate benefits of activities and help spread ideas } \\
\text { widely and quickly }\end{array}$ & $\begin{array}{l}\text { Entrepreneur in social responsible investment industry in France uses } \\
\text { the development of corporate social performance measurement as a } \\
\text { tool to develop its own legitimacy and power (Déjean et al., 2004). }\end{array}$ \\
\hline Theorizing & $\begin{array}{l}\text { Specifying a general organizational failing and justifying a } \\
\text { proposed solution }\end{array}$ & $\begin{array}{l}\text { Accounting firms in Alberta, Canada collectively use theorization to } \\
\text { define and redefine what it means to be a certified accountant and what } \\
\text { is an appropriate way of being organized (Greenwood et al., 2002). }\end{array}$ \\
\hline Building consensus & $\begin{array}{l}\text { Recruit powerful allies to their cause by offering some } \\
\text { tangible and/or intangible benefit to other existing actors }\end{array}$ & $\begin{array}{l}\text { Nation states sought to manipulate power configuration and create a } \\
\text { shared vision by allying with other powerful states to increase their } \\
\text { bargaining power, consequently reducing the diversity of opinions and } \\
\text { facilitating consensus among actors during the Kyoto negotiations } \\
\text { (Wijen and Ansari, 2007). }\end{array}$ \\
\hline Forging new collaborations & $\begin{array}{l}\text { Establishing new inter-actor collaborations to bring about } \\
\text { change through collective action }\end{array}$ & $\begin{array}{l}\text { Small groups that motivate, inspire, and enable engagement led to the } \\
\text { emergence of commercial microfinance in Bolivia (Dorado, 2013). }\end{array}$ \\
\hline
\end{tabular}

discuss possible trade-offs between collaborative and individual action for institutional change. Consequently, we argue that future studies should continue to investigate how institutional change is driven by sustainable entrepreneurship and suggest such studies take group and individual factors into account.

This article continues by reviewing sustainable and institutional entrepreneurship, and exploring the role of group collaboration in Section 2. In Section 3, we review torrefaction technology and present the qualitative methodology employed to examine our cases. Section 4 presents our findings, which is followed by a discussion in Section 5. We end with conclusions of our study and suggestions for future research in Section 6.

\section{Literature review}

In this section, we review sustainable entrepreneurship literature and bring institutional entrepreneurship and collaboration literature into the discussion. The overall aim is to gain a broader perspective of how actors aim to alter or create institutions.

\subsection{Sustainable entrepreneurship literature}

Although there is little definitional consensus, sustainable entrepreneurship has recently been defined as:

focused on the preservation of nature, life support, and community in the pursuit of perceived opportunities to bring into existence future products, processes, and services for gain, where gain is broadly construed to include economic and noneconomic gains to individuals, the economy, and society (Shepherd \& Patzelt, 2011).

Along these lines, Dean and McMullen (2007) and Cohen and Winn (2007) posit that various market failures represent opportunities for sustainable entrepreneurs to reduce environmentally degrading economic behaviors. From an innovation systems perspective, sustainable entrepreneurs find bottom-up solutions to transform and redirect the path of socio-economic development towards sustainable development (see Hekkert and Negro, 2009). Recently, Schaltegger and Wagner (2011) propose that sustainable entrepreneurship can be seen as an "innovative, market-oriented and personality driven form of creating economic and societal value by means of break-through environmentally or socially beneficial market or institutional innovations" (p. 226). They argue that sustainable entrepreneurship more often than not requires not only technological innovation but innovation in the business environment, market regulations, and societal norms and values. Actively modifying markets and institutions towards a more proenvironmental condition helps new sustainable products to become more competitive and legitimate (Thompson et al., 2011). For instance, sustainable entrepreneurs may help develop property rights, reduce transaction costs, disseminate new information, and even motivate government action that supports the sustainable allocation of environmental resources (Pacheco et al., 2010a,b). As such, sustainable entrepreneurs may support national well-being (Diener et al., 1995), education and health (UNDP, 2007), and social well-being (Wickrama and Mulford, 1996).

Despite research underlining the role sustainable entrepreneurship may have for institutional change, little research currently exists that explains how sustainable entrepreneurs might initiate this change. One explanation is that academic inquiry that combines sustainable development and entrepreneurship is still quite nascent. Reviews by Hall et al. (2010) and Thompson et al. (2011) show that research has mostly focused on organizational design (Parrish, 2009; Young and Tilley, 2006), 'niche' creation (Geels et al., 2008), small and large firm relations (Hockerts and Wüstenhagen, 2009), and innovation processes (Keskin et al., 2013). Research focusing on institutional change is more likely to highlight powerful environmental organizations' abilities to lobby rather than the role of emergent players. This under-researched aspect of sustainable entrepreneurship provides an opportunity to examine how sustainable entrepreneurs may attempt to induce institutional change.

\subsection{Institutional entrepreneurship literature}

Institutional entrepreneurship research specifically aims to understand how actors change institutions by drawing insights from a multitude of empirical contexts. Nevertheless, sustainable entrepreneurship remains absent from these studies. Current literature suggests that people act as institutional entrepreneurs when they attempt to institutionalize new practices, beliefs, values, and assumptions (Pacheco et al., 2010a,b) that alters existing institutions or creates new ones (Battilana et al., 2009). Institutional entrepreneurs "lead efforts to identify political opportunities, frame issues and problems, and mobilize constituencies" (Rao et al., 2000, p. 240). Accordingly, institutional entrepreneurship research has uncovered a variety of institutional change strategies that actors across a variety of contexts use to alter or create new institutions (overview provided in Table 1). 
First, actors may generate new symbols, construct new measures, and theorize solutions in order to communicate to other actors why they should support, or at least not resist, their institutionalization project (Garud et al., 2007). Symbols (such as pictures, diagrams, and logos) help to shape and share new ideas and initiate collective sense making (Lounsbury and Glynn, 2001). Creating new methods of quantification is another a way to provide measures of new activities and spread ideas widely and quickly (Déjean et al., 2004). Quantification involves the reduction of an object to subsets of elements, but how these elements are identified and quantified is established by the entrepreneur. Consequently, institutional entrepreneurs select or abandon dimensions that cannot pass the test of quantification (Porter, 1995) making measurement not neutral but as mechanism to establish and manipulate legitimacy vis-à-vis existing frameworks (Kondra and Hinings, 1998). Similarly, entrepreneurs may use theorization (Greenwood et al., 2002) to specify how a problem or inefficiency within existing practices justifies their proposed solution (Zilber, 2007). This involves efforts to discredit the status quo in order to lend support for newly proposed practices (Rao, 1998).

Second, building consensus often translates into materially rewarding supporters and punishing opponents. Given that sustainable entrepreneurs often lack the control over resources, they must recruit allies to their cause (Maguire et al., 2004). Yet, since entrepreneurs often have neither resources of their own nor power over other's resources (Dorado, 2005), support is contingent on the perception of some tangible and/or intangible benefit to other actors in the future, such as access to new markets, returns on investment, or reputational advantages (Colomy, 1998).

Finally, forging new collaborations with likeminded individuals is thought to be central to institutional entrepreneurship (Garud et al., 2007). Institutional entrepreneurs may choose to act in unison, such as in trade associations, to share responsibilities, networks, and resources to increase their resource-power and/or legitimacy (Stuart et al., 1999). However, there is also the additional dilemma of ensuring within-group participation, building trust, and reducing free-riding as individual interests may favor independence and secrecy rather than cooperation and transparency (Chilosi, 2003). These tensions may ultimately lead to coordination costs and vulnerability costs (Genefke, 2000). In the next section, we review intra-group collaboration literature to outline a few mechanisms that groups use to minimize self-interested behavior, and discuss how this could affect enactment of institutional change strategies.

\subsection{Intra-group collaboration literature}

Literature on intra-group collaborations generally suggests two mechanisms - the creation of formal or informal rules - that reduce self-interested behavior. On the one hand, the adoption or creation of bylaws and legal agreements binds participants into collaboration (Levine and Moreland, 1990). Formal rules work to constrain individual self-interest, but also enables actors to change institutions by allowing them to pool resources and build commitment (Lozano, 2007, 2012).

Informal rules differ from formal rules in that they are based on implicit and open-ended contracts rather than explicit and closedended contracts. These rules bind collaborators together by means of three social mechanisms: network access, macro-culture, and collective sanctions (Jones et al., 1997). While obeying informal rules permits access to the group (Burt and Knez, 1995), macroculture helps to bind collaborators because they share the same perceptions and understandings of their environment (Pfeffer and Leblebici, 1973). Collective sanctions, such inflicting reputational costs, structure behavior by condemning perpetrators (Kollock,
1994). Although we currently have little insight into these effects, the outcomes from collaboration are likely to have an additional effect on institutional change strategies.

In summary, sustainable entrepreneurs are likely to engage in institutional change however we have little insight into how this occurs. While institutional entrepreneurship provides a broader framework through which actors may alter or create institutions, it remains to be seen how sustainable entrepreneurs aim to engage with institutions. Lastly, although collaboration for institutional change is likely to influence the enactment of other institutional change strategies, little research provides insight into these effects.

\section{Methods}

This section describes the research context, case selection, and data collection procedures for this study. Furthermore, we detail the data analysis methods used to answer our research questions and the possible limitations of the selected methodology. It is important to note that a priori specification of constructs from institutional entrepreneurship research helped us to shape the initial design of theory-building research. Eisenhardt (1989) notes that this is valuable because it permits us to measure constructs more accurately. If these constructs prove important as the study progresses, then researchers have a firmer empirical grounding for the emergent theory. Although early identification of the possible constructs is helpful, it is equally important to recognize that they are tentative not determinative in this type of research.

\subsection{Research context selection - torrefaction in the Netherlands}

Recently a number of sustainable entrepreneurs have attempted to commercialize torrefaction. Torrefaction attempts to improve the quality and desirability of 'white pellet' biomass for electricity production. Torrefaction is a mild form of pyrolysis that slightly decreases mass although keeps energy content. As a result, the energy density of the torrefied biomass is higher than the original biomass and can be densified, usually into pellets, using conventional densification equipment (Arias et al., 2008). Prins et al. (2006) performed thermodynamic analysis of torrefaction and concluded that the concept is very promising in terms of $\mathrm{CO}_{2}$ emissions. Similarly, Stelt et al. (2011) evaluates the economic potential of torrefaction technology and concludes that it is the most cost-effective biomass plant for the Netherlands. Nonetheless, some of the energy content in original biomass is lost ( 10\%), the process does not reduce corrosive deposits on boiler tubes (Acharya et al., 2012), and commercial application has yet to be proven.

We selected this area since these entrepreneurs' activities lie outside or run contrary to dominant institutions. For example, only high quality woody biomass is permitted to be torrefied and blended with fossil coal in the Netherlands, which limits the available biomass supply and driving up costs. Thus it is necessary for these sustainable entrepreneurs to alter or create institutions to make torrefaction commercially viable.

\subsection{Case selection}

We followed Eisenhardt's (1989) theoretical sampling approach to choose cases. In mid-2010, we created a comprehensive list of all torrefaction biofuel projects in the Netherlands from the Dutch Chambers of Commerce, Dutch Ministry of Economics, Agriculture, and Innovation in the idea, implementation, and production stages. These lists were augmented with online industry association listings, networking with other scholars, and internet searches. We sought to narrow our search by setting a number of criteria such that participants must be: (a) independent entrepreneurs (creating 
Table 2

Entrepreneur and venture background.

\begin{tabular}{|c|c|c|c|c|c|}
\hline $\begin{array}{l}\text { Lead } \\
\text { entrepreneur }\end{array}$ & Age & Entrepreneur background & Education & $\begin{array}{l}\text { Venture, } \\
\text { founding }\end{array}$ & Key events over research timeframe \\
\hline Ray Nichols & 65 & $\begin{array}{l}\text { - Managing director }-1999-2004 \\
\text { - Operations manager-1986-1993 }\end{array}$ & $\begin{array}{l}\text { - University - MBA program } \\
\text {-1989-1991 }\end{array}$ & NewCoal, 2006 & $\begin{array}{l}\text { 2011: the company begins producing } \\
\text { bio-coal. 2012: energy companies } \\
\text { reluctant to adopt. }\end{array}$ \\
\hline Steve Cross & 53 & $\begin{array}{l}\text { - Owner-Trading Co. } 2010 \text { - Present } \\
\text { - Founder/Owner Electric Co. } 2004 \text { - } \\
\text { Present } \\
\text { - Founder/Owner Co. 2002-2007 }\end{array}$ & $\begin{array}{l}\text { - International Management } \\
\text { Development Program-1990 } \\
-1990\end{array}$ & GreenCoal, 2007 & $\begin{array}{l}\text { 2012: a fire broke out at the only } \\
\text { production facility. Fire damage is } \\
\text { repaired. 2013: low demand has kept } \\
\text { production at half capacity and a loss of } \\
\text { contract. }\end{array}$ \\
\hline Chris Parker & 50 & $\begin{array}{l}\text { - Investor/Partners in Sustainable Co. } \\
\text { 2003-2010 } \\
\text { - Founder/director Technology Co. } \\
\text { 2001-2003 }\end{array}$ & $\begin{array}{l}\text { - MBA, Entrepreneurship, } 1996 \\
-1998 \\
\text { - } \text { MSc, Applied Geophysics }\end{array}$ & CEnergy, 2008 & $\begin{array}{l}\text { 2010: starts construction of first facility. } \\
\text { 2011: wins WNF Cleantech and } \\
\text { Technology Pioneer award and } \\
\text { completes construction. 2012: wins } 13 \\
\text { million euro investment 2013: } \\
\text { Producing at quarter capacity. }\end{array}$ \\
\hline Cameron Robert & 49 & $\begin{array}{l}\text { - Managing Director Business Co. } 2005 \\
-2012 \\
\text { - Logistics Manager 2000-2005 }\end{array}$ & $\begin{array}{l}\text {-Economics and Business BA } \\
\text { Degree 1979-1985 }\end{array}$ & CleanCoal, 2006 & $\begin{array}{l}\text { 2011: an attempt to co-fire biocoal } \\
\text { resulted in an undesirable outcome. } \\
\text { This resulted in a loss of contract. } 2012 \text { : } \\
\text { the company has solved the problem } \\
\text { but has exited the market in } 2013 \text {. }\end{array}$ \\
\hline
\end{tabular}

a new business organization); (b) engaging in institutional entrepreneurship; (c) subject to the same institutional context; (d) using equivalent technologies; (e) targeting the same market; (f) have similar material inputs; (g) have identical objectives; and (h) have similar founding dates. Four cases met the above criteria. Three of the cases started and are members of the Dutch Torrefaction Association while the final case has chosen against membership and declined repeated offers to join. This sampling technique allows for a case comparison method to understand sustainable-institutional entrepreneurship both within and outside membership to the trade association. The names have been changed to ensure anonymity. Table 2 presents an overview of the individuals and ventures included in the study.

\subsection{Data collection}

We employed archival research methods (Ventresca and Mohr, 2002) and triangulated multiple sources of data (Denzin, 2006) to answer our research question (Table 3 presents the sources of the empirical data). We began by exploring the academic literature for ongoing controversies around biomass for electricity in the country. We also conducted twelve semi-structured interviews at production facilities and via the telephone with all four entrepreneurs. Each round of interview was recorded, transcribed, and lasted from one and a half to two hours. We collected additional data for each venture from many other archival sources. Lastly, one author created detailed notes from participation-observation by attending an association meeting, which also included engaging in a discussion and observing the members. This led to gaining access to all association meeting minutes and agendas since its inception in 2009.

\subsection{Data analysis}

Using NVivo software, the data analysis was carried out by the lead author following established qualitative data analysis techniques (Mayring, 2004), specifically comparative thematic analysis (Braun and Clarke, 2006). Thematic analysis is a method for identifying, analyzing and reporting patterns (themes) within data. The lead author first examined each empirical source multiple times per entrepreneur and carefully coded data into first order codes (a quotation, paragraph, or observation in a reduced number of words) and presented them to the co-authors. Next, the lead and co-authors matched first order codes into second order concepts that aimed to capture the general meaning of each code. Subsequently, we matched second-order concepts to create third order themes. In the final step, we compared the themes between the cases and between the association and the entrepreneur who did not join the association.

This longitudinal comparative case methodology has some advantages and limitations. The validity and reliability of findings is increased with a multiple case study design since it allows for within and between-case analysis. Moreover, the case selection processes allows us to control for contextual factors outlined in Section 3.2. We also used triangulation and participant-checking to increase the validity of the findings (Lincoln and Guba, 1985).

Table 3

Overview of sources of empirical qualitative data.

\begin{tabular}{|c|c|c|c|}
\hline Information source & Document type & Number of documents & Timeframe \\
\hline Publication journals & Academic research on torrefaction in $\mathrm{NL}$ & 14 & $1997-2012$ \\
\hline Entrepreneurs & Semi- structured interviews & 12 & $\begin{array}{l}\text { May 2011, September 2011-May 2012, } \\
\text { and January } 2013\end{array}$ \\
\hline Entrepreneurs & Nonparticipant observation/notes & 4 & May 2011 \\
\hline Entrepreneurs & Website & 4 & May 2011-January 2013 \\
\hline Trade Association & Participant observation/notes & 1 & April 2012 \\
\hline Trade Association & Website & 5 & May 2011-January 2013 \\
\hline Trade Association & Meeting agendas and minutes & 18 & June 2009-April 2012 \\
\hline Trade Association & Presentations & 3 & June 2009-January 2013 \\
\hline Internet & Newspaper/Magazine Articles & 15 & June 2009-January 2014 \\
\hline Internet & Pictures/Videos/Presentations & 5 & June 2009-January 2014 \\
\hline Other & Specification sheets/reports/letters & 3 & April 2012 \\
\hline Total & & 84 & \\
\hline
\end{tabular}


Table 4

Overview of institutional change strategies of Dutch torrefaction entrepreneurs.

\begin{tabular}{|c|c|c|}
\hline $\begin{array}{l}\text { Institutional } \\
\text { change strategy }\end{array}$ & Identifying concepts & Examples \\
\hline Creating symbols & $\begin{array}{l}\text { - Logo creation } \\
\text { - Diagram creation } \\
\text { - Slogan creation }\end{array}$ & $\begin{array}{l}\text { Stylized flame logo representing green combustion and their ecologically sound } \\
\text { business }{ }^{\mathrm{a}} \\
\text { Diagram representing the economic and technical sustainability of project }{ }^{\mathrm{b}} \\
\text { "It takes } 100 \text { million years to make coal, now it takes } 100 \text { seconds" (CEnergy- } \\
\text { presentation). }\end{array}$ \\
\hline Theorizing & $\begin{array}{l}\text { - Creating new narrative around tor- } \\
\text { refaction of biomass } \\
\text { - Solving biomass energy problems } \\
\text { through new torrefaction solutions }\end{array}$ & $\begin{array}{l}\text { "Sustainable energy is becoming increasingly important. Without biomass we } \\
\text { cannot achieve a relevant impact. We should deploy biomass at the lowest } \\
\text { possible price available. Torrefaction plays an important role to achieve that" } \\
\text { (Chris - Magazine article) } \\
\text { "Torrefied biomass has coal-like characteristics and can be fed into power plants } \\
\text { with coal directly. This additional investment will be very limited. Where white } \\
\text { pellets can be incinerated to ten to fifteen percent, we expect } 50 \text { percent more } \\
\text { torrefied biomass to be incinerated " (Ray - Newspaper article) } \\
\text { "Worldwide increasing demand for energy; Increasing demand for sustainable } \\
\text { energy; Reduction of } \mathrm{CO}_{2} \text {; Our Answer: Choice for torrefaction of a wide range of } \\
\text { biomass. Development of a new process with Use of existing machines to Lower } \\
\text { the present risks" (Cameron - Presentation) }\end{array}$ \\
\hline $\begin{array}{l}\text { Constructing } \\
\text { new measures }\end{array}$ & $\begin{array}{l}\text { - Measures to quantify emissions } \\
\text { savings } \\
\text { - Reports on characteristics of bio-coal }\end{array}$ & $\begin{array}{l}\text { "Torrefaction makes this possible and improves the grindability of the biomass } \\
\text { and increases the energy density typically to } 15-18.5 \mathrm{GJ} / \mathrm{m}^{3} \text {. The production } \\
\text { unit will be highly energy efficient because the heat }(>60 \%) \text { and will be used to } \\
\text { generate electricity" (Steve - Newspaper article). } \\
\text { "We did research with a university and with a Dutch engineering consultant } \\
\text { focusing on the } \mathrm{CO}_{2} \text { footprint of our business. [Utilities] have been investing } \\
\text { billions in sustainability. They want to make sure that whatever they contract as } \\
\text { fuel is indeed a sustainable fuel. So we were thorough and honest on the in- } \\
\text { formation about emissions" (Chris - Interview } 1 \text { ). }\end{array}$ \\
\hline Building consensus & $\begin{array}{l}\text { - Linking with supranational biomass } \\
\text { organizations } \\
\text { - Building partnerships with torre- } \\
\text { faction entrepreneurs across Europe }\end{array}$ & $\begin{array}{l}\text { "European Biomass Association and the torrefied biomass stakeholders have } \\
\text { decided to join forces and create the International Biomass Torrefaction Council } \\
\text { (IBTC). The main objectives are to promote torrefied biomass as an energy } \\
\text { carrier in Europe, undertake studies or projects, and to voice concerns to the } \\
\text { outside world" (IBTC website). } \\
\text { " } 20 \text { companies in Europe and USA support the torrefaction initiative and much } \\
\text { more already express their interest to join the group" (Association website). }\end{array}$ \\
\hline Forging new relations & $\begin{array}{l}\text { - Founding the Dutch Torrefaction } \\
\text { Association }\end{array}$ & $\begin{array}{l}\text { "A group of innovative entrepreneurs who wish to make a positive, effective and } \\
\text { concrete contribution towards a healthier climate" (Association Website) }\end{array}$ \\
\hline
\end{tabular}

\footnotetext{
${ }^{a}$ See Appendix 1.
}

b See Appendix 2.

Nonetheless, comparative case studies are also limited in several ways. First, we theorize based on a small group of sustainable entrepreneurs in a particular place and particular time. Thus, replicating this case scenario exactly is problematic as the findings may be to some degree context dependent. Second, the lead author was responsible for initial coding of the data. Having more than one author involved in coding would have been stronger evidence of findings. Although we have tried to increase the reliability and validity of our findings by being transparent, it remains possible that other researchers would code differently than described herein.

\section{Findings}

In this section, we present our findings on the strategies torrefaction entrepreneurs used to alter or create institutions (see Table 4 for an overview) and the effect of collaboration on these strategies (see Table 5).

\subsection{How sustainable entrepreneurs attempt to alter or create institutions}

Largely consistent with extant research on institutional entrepreneurship, the findings from data analysis suggest that sustainable entrepreneurs aim to alter or create institutions by creating new symbols, theorize problems and solutions, developing new measures, building a consensus and forging new entrepreneurial relations.

\subsubsection{Creating new symbols}

We found that the entrepreneurs in our sample created new symbols to re-shape and share new ideas about the properties and outcomes of torrefaction. For example, all of the cases developed logos and slogans to capture the essence of torrefaction technology (see Appendix 1 for an example). These logos all symbolized a flame combined with some symbolic element of environmentalism, such as green color and a tree. The flame symbol linked the idea of torrefaction to current imagery of combustion for the production of energy, but clearly indicated an element of environmental preservation that breaks with associations to coal. Another entrepreneur provided a slogan that summarizes torrefaction: "It takes 100 million years to make coal, now it takes 100 seconds" (CEnergy-presentation). Slogans helped summarize and position the sustainable entrepreneurs' objectives, which helped to alter understanding about the typical characteristics and limitations of biomass. Lastly, the cases also developed diagrams representing the economic and technical sustainability of torrefaction projects (see Appendix 2). These diagrams were used to educate potential clients and suppliers of their plans (Observations and Videos). Diagrams played an important role in translating complex processes of torrefaction into easily digestible ideas. In sum, because much of the strength of existing institutions is embedded in the taken-for-granted meanings, sustainable entrepreneurs worked to renegotiate and propose alternatives to proliferate their ideas through creating new symbols.

\subsubsection{Theorizing change}

In addition, we found that sustainable entrepreneurs aimed to theorize the problems and solutions of biomass. Theorization 
Table 5

Differences in Institutional change strategies between individual and group cases.

\begin{tabular}{|c|c|c|}
\hline Differences & Explanation & Examples \\
\hline Mode & $\begin{array}{l}\text { Group: Formal and informal rules enable the creation of } \\
\text { accessible modes of institutional change strategies. } \\
\text { Individual: Individual increases adaptability by specializing } \\
\text { in certain institutional change strategies }\end{array}$ & $\begin{array}{l}\text { "A group of innovative entrepreneurs who wish to make a positive, effective and } \\
\text { concrete contribution towards a healthier climate" (Association Website). } \\
\text { "Some of our colleagues have been screaming in the market that they can } \\
\text { deliver } 45-50,000 \text { tons of biocoal a year for the past three years. We decided not } \\
\text { to do this. We said let's wait, process our material and based on the results we } \\
\text { can go to the market" (Steve - Interview } 1 \text { ). }\end{array}$ \\
\hline Scope & $\begin{array}{l}\text { Group: Formal and informal rules enables the creation of } \\
\text { diverse scope of institutional change strategies. } \\
\text { Individual: Individual increases adaptability by specializing } \\
\text { in certain institutional change strategies }\end{array}$ & $\begin{array}{l}\text { "I think that was the very idea behind the [association]. Today everyone knows. } \\
\text { Five years ago nobody knew" (Ray - Interview 2) } \\
\text { Steve specialized in generating new data on everything from } \mathrm{CO}_{2} \text { savings, to } \\
\text { production capacity and functionality; to environmental safety in order to } \\
\text { 'prove' the positive impacts he could have if markets and institutions would be } \\
\text { altered in his favor (Presentations/Observational Notes/Website). }\end{array}$ \\
\hline \multirow[t]{2}{*}{ Scale } & $\begin{array}{l}\text { Group: Formal and informal rules led to an inter- } \\
\text { organizational scale of relations. }\end{array}$ & $\begin{array}{l}\text { "We noticed there were also companies coming out from Europe starting in the } \\
\text { field but we were a bit ahead of them in the Netherlands. We had an idea that if } \\
\text { you do not join forces you will be played out against each other" (Ray - } \\
\text { Interview 2) }\end{array}$ \\
\hline & $\begin{array}{l}\text { Individual: Individuals reduced the scale of social } \\
\text { interaction allowing for tailoring through interpersonal } \\
\text { relations. }\end{array}$ & $\begin{array}{l}\text { "If the larger energy corporations are not capable with their lobby to change the } \\
\text { politics around it, who are we to achieve that?" (Steve - Interview } 1 \text { ) } \\
\text { "[the association] is working at a national level and [I'm] looking at a provincial } \\
\text { level" (Steve - Interview 2) }\end{array}$ \\
\hline
\end{tabular}

illuminates how a problem can be solved, what is required to solve it, and encourages others to participate in legitimating bio-coal. For instance, Cameron said, "if you read the papers, all the European leaders come together in Berlin last year said 'we're going to reduce $\mathrm{CO}_{2}$ output by $20 \%$ in 2020 '. How are you going to do that?" (Interview 1). All the cases argued that bio-coal has "coal-like characteristics" which allows it to be "fed into power plants directly", which helps meet the EU's sustainability goals (Ray Newspaper article). For example, Chris stated:

"You can use the existing assets if you want to co-fire [white pellets] but still you need to do quite extensive retrofitting of a plant in order to enable at least partly co-firing. The thinking behind torrefaction is really what if we could make the biomass in a coal-like product so you could use it onsite as coal; coal yards, coal fuel lines?"(Chris - Interview 1).

The sustainable entrepreneurs also developed pro-/antagonistic labels to help make sense of their position, and identify supporters and skeptics in the energy field. For example, the entrepreneurs complained of coal companies and other status quo supporters that damage the natural environment from "business as usual" (Ray Interview 1). Fossil coal was related to a "damaging drug, to which society is addicted" and energy companies are the dealers (Cameron - Interview 1). Alternatively, Ray linked with a prominent sustainable development scholar in the Netherlands supportive to their cause (2011 Meeting Minutes).

Consequently, through theorization, sustainable entrepreneurs attempt to discredit the status quo and present alternatives in ways that resonate with other actors who have the power to legitimate their activities.

\subsubsection{Developing new measures}

Next, we found that the sustainable entrepreneurs aimed to develop new measures to quantify the characteristics of bio-coal, the sustainability of supply chains and the possible carbon emission savings. We observed the sustainable entrepreneurs aiming to develop these measures to (re)define assumptions, beliefs, and rules associated with biomass material and to become less reliant on discursive strategies. For example, they relied on measurement to communicate the benefits of torrefaction, characteristics of biocoal, and environmental benefits as a replacement fuel widely and quickly. One entrepreneur said:
"Torrefaction makes this possible and improves the grindability of the biomass and increases the energy density typically to $15-18.5 \mathrm{GJ} / \mathrm{m}^{3}$. The production unit will be highly energy efficient because the heat ( $>60 \%)$ and will be used to generate electricity" (Steve - Newspaper article).

Another entrepreneur clarified:

"We did is we did some initial research with a university and with one of the Dutch engineering consultants. One of the focuses of research was on the $\mathrm{CO}_{2}$ footprint of our business. [Utilities] have been investing billions in sustainability. They want to make sure that whatever they do, whatever they contract as fuel is indeed a sustainable fuel. So we were thorough and honest on the information about emissions, which is totally key" (Chris - Interview 1).

In sum, sustainable entrepreneurs design and employ measurement techniques to reduce uncertainty and ensure that main stakeholders view their products and activities as legitimate.

\subsubsection{Building consensus}

Results from data analysis showed that sustainable entrepreneurs aimed to build a consensus by recruiting powerful allies in the energy sector to their cause, and by offering some tangible and/ or intangible benefit to existing energy companies and policy makers. For example, the entrepreneurs approached policy makers to enact laws that would make bio-coal legal and obligatory, and to specify how it is made, sold, and used safely. One entrepreneur noted:

"It's important that you inform governments. Governments are always willing to change but they need to have that information. They are in the big buildings and they also don't know what's happening out there" (Chris - Interview 2).

Sustainable entrepreneurs also aimed to link torrefaction to other biofuel organizations and supranational biomass associations to help promote their new biofuel. For example, they created the International Biomass Torrefaction Council (IBTC) to promote the use of torrefied biomass in Europe through "studies and a common voice", and linked this to the European Biomass Association in Brussels (IBTC website). The aim of these collaborations was to ensure institutional change even in the face of resistance by 
leveraging European, national, and provincial governments to offer financial incentives or impose penalties to encourage the use of bio-coal. Moreover, they aimed to build partnerships and encourage other torrefaction entrepreneurs across Europe (Association website). Building consensus thus involved actions to recruit powerful allies to help reshape institutions and overcome their own inability to alter institutions alone.

\subsubsection{Forging new relations}

We found that the sustainable entrepreneurs, except Steve, joined to establish the Dutch Torrefaction Association to bring about institutional change through collective action. Forging new relations allowed the entrepreneurs to share responsibilities, networks, and resources. The three sustainable entrepreneurs collaborated because it increased perspective, knowledge, and approaches to solve problems while at the same time offering benefits to all those involved in the process. For instance, the group billed themselves as "a group of innovative entrepreneurs who wish to make a positive, effective and concrete contribution towards a healthier climate" (Association Website). Moreover, these entrepreneurs joined the group because "if you do not join forces you will be played out against each other" (Ray - Interview 1). Another entrepreneur added "if you are as a small business entrepreneur in this energy field, you walk as mice between the giants. I think we better can see what we can do for each other because there is so much to do and so much opportunity" (Cameron Interview 2). As we will see in detail in the next section, the group members organized to pool their resources, specialize in institutional change tasks, and develop a broader sense of criticism of the status quo.

In conclusion, our findings show that torrefaction entrepreneurs aim to alter or create institutions through a number of institutional change strategies. These resulting strategies are consistent with literature reviewed in Section 2.2 adding to their validity and reliability. However, over the course of the study we also found that the enactment of these strategies varied in content and range between participants. In the next section, we explore a main driver of these differences by examining the difference between sustainable entrepreneurs that joined in an association and one case that did not.

\subsection{How forging new relations affects the mode and scope of institutional change strategies}

We found that forging new relations with other sustainable entrepreneurs required making formal and informal rules to ensure honesty and participation. These rules also motivated more accessible modes and diverse scope of institutional change strategies. Contrastingly, the case acting alone narrowed the mode and scope of institutional change strategies which enabled him to be adaptable to changing situations. The remainder of this section provides examples and details from the cases leading to propositions.

The association created the 'rules of procedure' that outlined the distribution of board members, the question of how to deal with new members, opening a bank account, and monetary contributions (2009 Association Minutes). The creation of these formal rules allowed the group to undertake the more types and forms of institutional change strategies. For example, the association hired a consultant to explore the need to register with REACH, a European Community Regulation on chemicals and their safe use (2010 Meeting Minutes). The REACH program created an in-depth report on the sustainability of the biomass material used in torrefaction (new measure strategy), which was of considerable interest from entrepreneurs in the United States, the United Kingdom, and Lithuania (2011 Meeting minutes).
In addition, the pooling of resources allowed the group to jointly create a website to communicate their mission (symbols and theorization strategy). Ray stated that the website is "how you make a voice. I think that was the very idea behind the [association]. It's also about education. We have a website with some basic information on what torrefaction is. Today everyone knows. Five years ago nobody knew" (Ray - Interview 2). The pooling of resources also funded their participation in conferences and symposia where they linked their activities to meta-narratives of sustainable development (creating new stories and theorizing strategy). All three entrepreneurs presented elements of torrefaction as a business opportunity at the 2011 Energy Delta Convention 2011 and Bio-power Generation Congress 2011 (2011 Meeting minutes). Lastly, the association gave a master class on torrefaction in February 2011 that explained what the entrepreneurs aim to achieve through torrefaction technology (2011 Meeting minutes).

We also noted how informal rules also motivate institutional change strategies by jointly criticizing the status-quo. While informal rules enforce participation and equality, the informal rules also led to trust. Ray stated that "the first time that everyone is a bit careful and no one tells you too much. But after a while people do trust each other" (Interview 3). Chris additionally said that:

"You can pick up the phone and say Ray, "can you do me a favor; can you ship me some product for a customer that I have?' I think it's good for the individual company and for the sector building as such" (Chris - Interview 3).

We found that trust allowed for a broadened extent of criticism. The association views themselves as "a regime of the second industrial revolution" while utility companies "are losing influence" but "sit in their castle and try to hold their position" (Chris Interview 2). This translated into writing and publishing articles in favor of torrefaction (creating new stories and theorizing strategy). The association, for instance, wrote a letter to NEN, a non-profit standardization organization to argue that since the definition of "sustainability can be certified by the utility companies themselves, this is a major barrier to meet expectations of clients since they can move the definition of "sustainability"' (Observation of Association Meeting 2012). They also wrote that utility companies are unwilling to accept any price of transportation of torrefied materials, even though they incur much more costs transporting fossil fuels. "The energy companies are discriminating against torrefaction on the basis of transportation costs" (2012 Meeting Minutes). The letters aimed to develop a united front within group to present a clear message to (unwilling) clients or other organizations. The group wrote these articles and letters to communicate the message of torrefaction: "Consistently repeating that message, because it's not deaf ears to which you're talking but it's ears reluctant to believe, so it's repetition of the message" (Chris - Interview 1).

In summary, the emergent rules designed to overcome collective action problems resulted in a pooling of resources, trust, and broadened the latitude for criticizing fossil fuels. In turn, these provided a catalyst for assessable and diverse institutional change strategies. Therefore, we propose:

Proposition 1. The creation of formal and informal rules allows for the pooling of scarce resources, task specialization, trust, and broadens the extent of criticism, which in turn enables the creation of accessible modes and a diverse scope of institutional change strategies.

Unencumbered by rules, Steve approached institutional change very differently. Steven envisioned institutional change as mostly out of control of any one individual, which differed from the association. For example, Steve believes that "in the end it's all about 
the best technology, the technology with the highest efficiency" (Steve - Interview 2). Nevertheless, he sees the biggest problem to market access as what 'proves' that it works:

"The definition that it works is kind of a variable. Should it work one hour, three years, or any problem with low maintenance? It's a very broad definition. I can sell right now at 7 million Euros a piece. But it's all depending on a working installation. But the word 'working' is not defined yet, then you can't get the finance from the finance community" (Steve - Interview 1).

Since a 'working' installation is moving and political, Steve concentrates on creating new measures as an institutional change strategy. He generated new data on everything from $\mathrm{CO}_{2}$ savings, to production capacity and functionality, to environmental safety in order to 'prove' the positive impacts he could have if markets and institutions would be altered in his favor (Presentations/Observational Notes/Website).

Furthermore, contrasting with the group, Steve demonstrated an aversion to engaging in politics: "I think the [torrefaction association] is nice but it has absolutely no punch, no power to make a difference. They don't have millions left to start a lobby process" (Steve - Interview 2). On the one hand, Steve does view broad institutional change as necessary for the success of torrefaction: "maybe change the price of carbon credit, or make it tougher for the power industry to achieve their targets, so they are obliged to buy more. Or have different rulings where some of the cost of producing green energy is charged to the end user" (Steve - Interview 2). On the other hand, he views obstructions to torrefaction fundamentally beyond his control. Regarding the association's institutional change approach, he stated "if the larger energy corporations are not capable with their lobby to change the politics around it, who are we to achieve that?" (Steve - Interview 1). Consequently, he narrows his institutional change strategy directed at altering perceptions of 'working' torrefaction products to immediate stakeholders through quantifying its benefits, while viewing market situations and European regulations as inevitable.

The narrow scope of institutional change strategies however allowed Steve to be able to change tact as the need arose, making him able adaptable to changing situations quickly. For example, after losing a contract with a main client, he was able to receive subsidies that provide a discount on taxes in return for tests of "various types of biomass using the investments we have made. We are using those subsidies to help us with financing" (Steve Interview 2). Accordingly, we posit that:

Proposition 2. Individual sustainable entrepreneurs seeking to change institutions aim to increase adaptability by specializing in certain institutional change strategies.

\subsection{How collaboration affects the scale of institutional change strategies}

Our findings revealed that the association and the individual differed in their scale of enactment. While the association's rules led to an inter-organizational scale aimed at building a consensus on the European level, Steve reduced the scale of institutional change strategies. The remainder of this section provides examples and details from the cases leading to propositions.

The association initiated a standardization process with the aim of expanding their influence in the European bio-energy field (building consensus strategy). Today, utility companies purchase varying types of coal from the global marketplace, and use international specifications to ensure maximum efficiency from them. Similarly, utility companies are interested in establishing new specifications of biomass material to control the access and types of products available. The torrefaction entrepreneurs fear that utility companies will make "the rules of the game" (Cameron - Interview 2 ), set a product standard themselves, which would greatly reduce the types of biomass available for torrefaction. This had previously happened to their 'white pellet' precursors: "[Utility companies] were looking for one specific specification sheet for white pellets at the time. That was very big hurdle for the new producers because everybody had to fulfill these specs. Where did the specs come from? They came from the [utility companies] (Cameron - Interview 1 )". Over time, the collective negotiated with one another to develop their own specifications around a common product that would allow for greater variety of biomass characteristics (Specifications Sheet/Association Minutes).

Next, the association built a partnership with the European Biomass Association to implement their product specification standards. The group works "within the arena of government, politics, management and private producers" and "we are working hard towards a sound national positioning for torrefaction" (Association Website). They created the European Torrefaction Association (EURTA) to reach out to other European torrefaction entrepreneurs. Ray also successfully partnered EURTA with the European Biomass Association in Brussels which lobbies the European Commission in support for bio-based energy. This allowed the group to spearhead the development of International Standards (ISO) for torrefied biomass based on the association's previous negotiations, which effectively sets the European standard for torrefaction, taking control away from large utility companies (2012 Meeting Minutes/EURTA website). Accordingly, we propose:

Proposition 3. Formal and informal rules broadened the extent of criticism which led to an inter-organizational scale of institutional change strategies aimed at maximizing influence.

Compared to the association, Steve built new relations with likeminded provincial politicians, foundations, and research institute in close spatial proximity to his facility. For example, he stated that his contacts are "a one-to-one basis. It worked very well and it's a very positive relationship. We have received subsidies and [our contact] can bring us into contact with other parts of the government" (Steve - Interview 3). This has the added benefit of building trust relationships with specific people and being able to tailor institutional change strategy. For example, Steve explained how he built a relationship with "a middle man" employee within a government agency "who specialized in subsidies" (Steve - Interview 3 ). The employee is "getting paid on a no cure/no pay basis. He is screening all the programs and when there is something which he feels could be interesting for us he contacts us" (Steve - Interview 3 ). Consequently, while the association structure broadens the extent of criticism leading to broader scale of social relations, institutional entrepreneurship individually is conducted at an interpersonal level, which allows for tailoring institutional change strategies.

Proposition 4. Individual sustainable entrepreneurs aiming to alter institutions reduce the scale of social interaction allowing for tailoring of institutional change strategy through interpersonal relations.

\section{Discussion}

The present findings have three implications for research on sustainable entrepreneurship. First, we argued that very little research investigates how sustainable entrepreneurs alter or create institutions. Empirical findings show that sustainable entrepreneurs: create new symbols; construct new measures; theorize current failings and justify solutions; build consensus; and forge 
new collaborations to alter or create new institutions. This contributes to literature by not only clarifying the mechanisms through which sustainable entrepreneurs instigate institutional change, but by also building a bridge between literature on sustainable and institutional entrepreneurship as suggested by Schaltegger and Wagner (2011). While these findings are largely consistent with findings from institutional entrepreneurship, we see this as additive to sustainable entrepreneurship research. Combining a case study with literature from another area makes our results stronger at a higher conceptual level (Eisenhardt, 1989). This is particularly crucial in case based research because the emergent theory rests on a very limited number of cases. Accordingly, further corroboration by linking evidence with institutional entrepreneurship improves internal validity and generalizability of our findings.

Furthermore, whereas the majority of sustainable entrepreneurship research focuses on defining sustainable entrepreneurship (Parrish, 2009), identifying the conditions of emergence (Keskin et al., 2013), and small and large firm relations (Hockerts and Wüstenhagen, 2009), this article contributes to literature on how sustainable entrepreneurs aim to modify or produce institutions. This re-direction moves attention from the macro- and meso-level (Clark and Lund, 2007) towards the microentrepreneurial processes that pioneer and institutionalize sustainable innovations. Thus, this article has similarities with research examining the social dynamics of 'niche protection' (Ulmanen et al., 2009) although it differs in that it explicates the various micro-level institutional change strategies that aim to have an effect at the macro-level (Jennings et al., 2013).

Second, we found that the enactment of institutional change strategies varies per entrepreneur. In Sections 4.2 and 4.3 we found that these differences are likely due to the rules developed to prevent free-riding behavior. These formal and informal rules not only constrained individual self-interests, but provided a catalyst for institutional change strategies. These findings therefore contribute to literature by illustrating why institutional change strategies differ between sustainable entrepreneurs, despite an identical institutional context. Accordingly, taking individual and group level factors into account is necessary in further explorations of sustainable-institutional entrepreneurship.

Third, our findings suggest some trade-offs between collaborative and individual action for institutional change. Current research typically emphasizes network building or 'running in packs' to develop 'niche' markets (Verbong and Geels, 2007). Similarly, we show that since collaboration offers more diverse modes and assessable scope of strategies, it is likely to increase the chances of institutional change by reducing the reliance on any one institutional change strategy. Nevertheless, collaboration may come at the risk of being viewed as a group of subjectively self-interested entrepreneurs because "it is not much of a stretch to suggest that storytelling could result in misrepresentation" (Rutherford et al., 2009, p. 952). Developing targeted institutional change strategies at specific, powerful individuals, on the other hand, may allow an individual to tailor strategies and increase chances of affecting institutional change, albeit at significant opportunity costs. As such, 'going at it alone' may assist in precision, but possibly comes at the cost of being able to influence a broader audience.

\section{Conclusion}

This study aimed to answer the question of how sustainable entrepreneurs go about altering or creating new institutions. We conclude sustainable entrepreneurs create new symbols, theorize current problems and solutions, construct new measures, build consensus, and forge new collaboration to alter or create new institutions. Moreover, we conclude that forging new collaborations has three feedback effects on institutional change strategies: (1) it broadens the modes; (2) allows for an increased scope; and (3) increases the scale of institutional change strategies. Contrarily, sustainable entrepreneurs acting alone aim to specialize in institutional change strategies to increase the adaptability of claims by leveraging their inter-personal networks.

This study, however, does have some limitations. First, we chose a sample that allowed for theorizing on institutional change strategies and individual-group differences. One could argue that this sample produces rather idiosyncratic findings particular to torrefaction. It is important to keep in mind that the forms of institutional change strategies are likely to vary depending on the age of the industry, structure of the industry, and number of participants involved in change among others making large case, cross-study comparisons problematic. Second, the analysis in the study is built upon torrefaction in the Netherlands, which has yet to make a meaningful impact on the energy sector. This may point to the inefficacy of institution change strategies described here. On the other hand, the emergence of these new ventures is not unlike other industrial contexts: there were no field leaders from the outset; there was no definite identity, nor prior sets of accepted norms and values, or stable inter-personal or inter-organizational relationships. Accordingly, our careful selection of cases provides first insight into institutional change strategies, and ample room for future research to add to the emergent framework.

This study has two main suggestions for future research. First, studies should continue to investigate how institutional change is driven by sustainable entrepreneurship by building upon the concepts elaborated here. Key future research questions are: Do the strategies used by sustainable entrepreneurs to engage in institutional change vary across other contexts and why? Is there some combination of institutional change strategies that are more likely to lead to more pro-environmental institutions? How do these strategies compare to cases that were successful in altering or creating institutions? Moreover, future studies could further explore how group collaboration both enables and constrains actions for institutional change: Do the strategies identified here differ as groups become larger? Is there an optimal size of a group to tip the scales towards pro-environmental institutions in a given region? Is there an optimal composition of a group that provides access and maximizes influence for institutional change? Clearly, there remain many research opportunities that combine sustainable and institutional entrepreneurship perspectives.

\section{Appendix 1. Logo development}

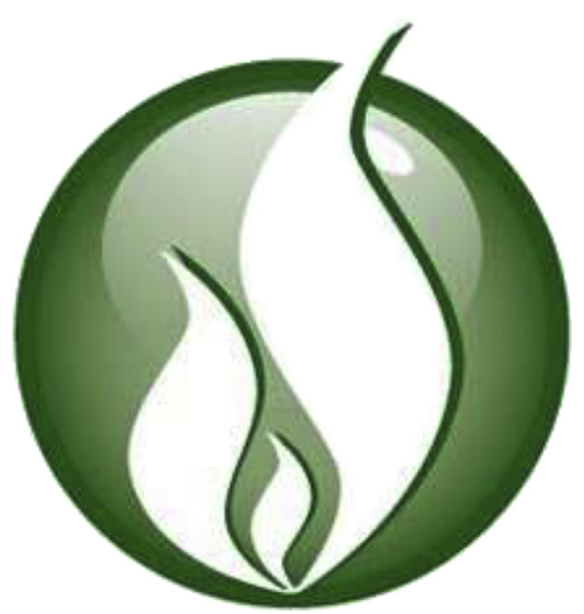


Appendix 2. Example torrefaction diagram

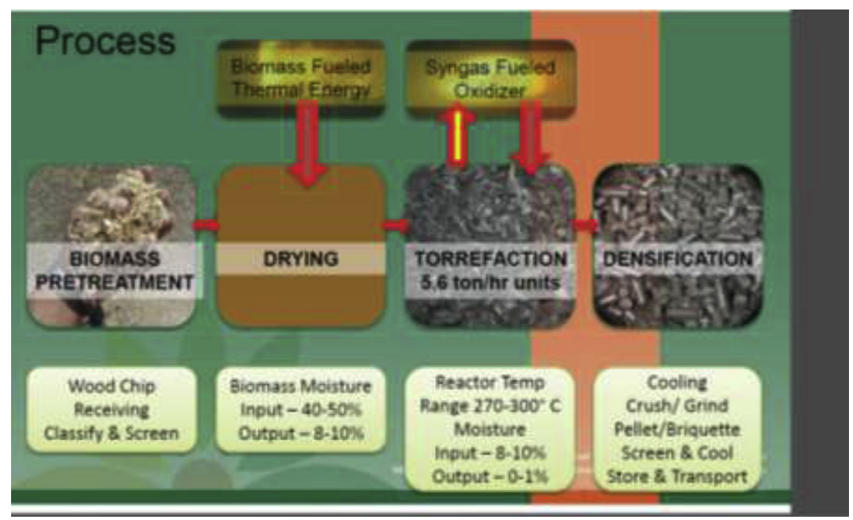

\section{References}

Acharya, B., Sule, I., Dutta, A., 2012. A review on advances of torrefaction technologies for biomass processing. Biomass Convers. Biorefin. 2 (4), 349-369. http:// dx.doi.org/10.1007/s13399-012-0058-y.

Arias, B., Pevida, C., Fermoso, J., 2008. Influence of torrefaction on the grindability and reactivity of woody biomass. Fuel Process. Technol. 89 (2), 169-175.

Battilana, J., Leca, B., Boxenbaum, E., 2009. How actors change institutions: towards a theory of institutional entrepreneurship. Acad. Manag. Ann. 3 (1), 65-107.

Braun, V., Clarke, V., 2006. Using thematic analysis in psychology. Qual. Res. Psychol., 37-41 (January 2014).

Burt, R.S., Knez, M., 1995. Trust and third-party gossip. In: Kramer, R., Tyler, T. (Eds.), Trust in Organizations: Frontiers of Theory and Research. Sage, Thousand Oaks, CA, pp. 68-69.

Chilosi, A., 2003. Coordination, Cooperation, and the Extended Coasean Approach to Economic Policy. Facolta di Scienze Politiche, Pisa.

Clark, W., Lund, H., 2007. Sustainable development in practice. J. Clean. Prod. 15 (3), $253-258$.

Cohen, B., Winn, M.I., 2007. Market imperfections, opportunity and sustainable entrepreneurship. J. Bus. Ventur. 22 (1), 29-49.

Colomy, P., 1998. Neofunctionalism and neoinstitutionalism: human agency and interest in institutional change. Sociol. Forum 13 (2), 265-300.

Dean, T.J., McMullen, J.S., 2007. Toward a theory of sustainable entrepreneurship: reducing environmental degradation through entrepreneurial action. J. Bus. Ventur. 22 (1), 50-76. http://dx.doi.org/10.1016/j.jbusvent.2005.09.003.

Déjean, F., Gond, J.-P.J., Leca, B., 2004. Measuring the unmeasured: an institutional entrepreneur strategy in an emerging industry. Hum. Relat. 57 (6), 741-764. http://dx.doi.org/10.1177/0018726704044954.

Denzin, N.K., 2006. Sociological Methods: a Sourcebook. Aldine Transaction, London.

Diener, E., Diener, M., Diener, C., 1995. Factors predicting the subjective well-being of nations. J. Personal. Soc. Psychol. 69, 851-864. http://dx.doi.org/10.1037/ 0022-3514.69.5.851.

DiMaggio, P.J., Powell, W.W., 1983. The iron cage revisited: institutional isomorphism and collective rationality in organizational fields. Am. Sociol. Rev. 48 (2), $147-160$

Dorado, S., 2005. Institutional entrepreneurship, partaking, and convening. Organ. Stud. 26 (3), 385-414. http://dx.doi.org/10.1177/0170840605050873.

Dorado, S., 2013. Small groups as context for institutional entrepreneurship: an exploration of the emergence of commercial microfinance in Bolivia. Organ. Stud. 34 (4), 533-557.

Eisenhardt, K.M., 1989. Building theories from case study research. Acad. Manag. Rev. 14 (4), 532-550.

Garud, R., Hardy, C., Maguire, S., 2007. Institutional entrepreneurship as embedded Agency: an introduction to the special issue. Organ. Stud. 28 (7), 957-969. http://dx.doi.org/10.1177/0170840607078958.

Geels, F.W., Hekkert, M.P., Jacobsson, S., 2008. The Dynamics of Sustainable Innovation Journeys.

Genefke, J., 2000. Collaboration Costs! University of Aarhus Department of Management, Aarhus.

Greenwood, R., Hinings, C.R., Suddaby, R., 2002. Theorizing change: the role of professional associations in the transformation of institutionalized fields. Acad. Manag. 45 (1), 58-80.

Hall, J., Daneke, G., Lenox, M., 2010. Sustainable development and entrepreneurship: past contributions and future directions. J. Bus. Ventur. 25 (5), 439-448. http://dx.doi.org/10.1016/j.jbusvent.2010.01.002.

Hekkert, M.P., Negro, S.O., 2009. Functions of innovation systems as a framework to understand sustainable technological change: empirical evidence for earlier claims. Technol. Forecast. Soc. Change 76 (4), 584-594.
Hockerts, K., Wüstenhagen, R., 2009. Greening Goliaths versus emerging Davids-theorizing about the role of incumbents and new entrants in sustainable entrepreneurship. J. Bus. Ventur. 25, 481-492. http://dx.doi.org/10.1016/ j.jbusvent.2009.07.005.

Jennings, P.D., Greenwood, R., Lounsbury, M.D., Suddaby, R., 2013. Institutions, entrepreneurs, and communities: a special issue on entrepreneurship. J. Bus. Ventur. 28 (1), 1-9. http://dx.doi.org/10.1016/j.jbusvent.2012.07.001.

Jones, C., Hesterly, W., Borgatti, S., 1997. A general theory of network governance: exchange conditions and social mechanisms. Acad. Manag. Rev. 22 (4), 911-945.

Keskin, D., Diehl, J.C., Molenaar, N., 2013. Innovation process of new ventures driven by sustainability. J. Clean. Prod. 45, 50-60.

Kollock, P., 1994. The emergence of exchange structures: an experimental study of uncertainty, commitment, and trust. Am. J. Sociol. 100, 313. http://dx.doi.org/ $10.1086 / 230539$.

Kondra, A.Z., Hinings, C.R., 1998. Organizational diversity and change in institutional theory. Organ. Stud.19, 743-767. http://dx.doi.org/10.1177/017084069801900502.

Levine, J., Moreland, R., 1990. Progress in small group research. Annu. Rev. Psychol. 41, 585-634.

Lincoln, Y.S., Guba, E.G., 1985. Naturalist Inquiry, first ed. Sage Publications Ltd, Newbury Park, CA.

Lounsbury, M., Glynn, M., 2001. Cultural entrepreneurship: stories, legitimacy, and the acquisition of resources. Strateg. Manag. J. 22 (6/7), 545-564. http:/ dx.doi.org/10.1002/smj.188. Special Issue: Strategic Entrepreneurship: Entrepreneurial Strategies for Wealth Creation.

Lozano, R., 2007. Collaboration as a pathway for sustainability. Sustain. Dev., 370-381, 15(March).

Lozano, R., 2012. Addressing stakeholders and better contributing to sustainability through game theory. J. Corp. Citizsh. 43, 44-62.

Maguire, S., Hardy, C., Lawrence, T., 2004. Institutional entrepreneurship in emerging fields: HIV/AIDS treatment advocacy in Canada. Acad. Manag. J. 47 (5), 657-679.

Mayring, P., 2004. Qualitative content analysis. A Companion Qual. Res., 266-269.

Pacheco, D.F., Dean, T.J., Payne, D.S., 2010a. Escaping the green prison: entrepreneurship and the creation of opportunities for sustainable development. J. Bus. Ventur. 25 (5), 464-480. http://dx.doi.org/10.1016/j.jbusvent.2009.07.006.

Pacheco, D.F., York, J.G., Dean, T.J., Sarasvathy, S.D., 2010b. The coevolution of institutional entrepreneurship: a tale of two theories. J. Manag. 36 (4), 974-1010. http://dx.doi.org/10.1177/0149206309360280.

Parrish, B.D., 2009. Sustainability-driven entrepreneurship: principles of organization design. J. Bus. Ventur. 25 (5), 510-523. http://dx.doi.org/10.1016/ j.jbusvent.2009.05.005.

Pfeffer, J., Leblebici, H., 1973. Executive recruitment and the development of interfirm organizations. Adm. Sci. Q. 18, 449-461. http://dx.doi.org/10.2307/2392198.

Porter, T.M., 1995. Trust in Numbers: the Pursuit of Objectivity in Science and Public Life. Princeton University Press, Princeton, N.J.

Prins, M., Ptasinski, K., Janssen, F., 2006. More efficient biomass gasification via torrefaction. Energy 31 (15), 3458-3470.

Rao, H., 1998. Caveat emptor: the construction of nonprofit consumer watchdog organizations. Am. J. Sociol. 103 (4), 912-961.

Rao, H., Morrill, C., Zald, M.N., 2000. Power plays: how social movements and collective action create new organizational forms. In: Staw, B., Sutton, R. (Eds.), Research in Organizational Behavior, 22nd ed., vol. 22. Elsevier, New York, New York, USA, pp. 237-281.

Rutherford, M.W., Buller, P.F., Stebbins, J.M., 2009. Ethical considerations of the legitimacy lie. Entrepreneursh. Theory Pract. 33 (4), 949-964. http://dx.doi.org/ 10.1111/j.1540-6520.2009.00310.x.

Schaltegger, S., Wagner, M., 2011. Sustainable entrepreneurship and sustainability innovation: categories and interactions. Bus. Strategy Environ. 20 (4), 222-237. http://dx.doi.org/10.1002/bse.682.

Shepherd, D. a, Patzelt, H., 2011. The new field of sustainable entrepreneurship: studying entrepreneurial action Linking? What is to be sustained? With? What is to Be developed? Entrepreneursh. Theory Pract. 35 (1), 137-163. http:// dx.doi.org/10.1111/j.1540-6520.2010.00426.x.

Stelt, M. Van der, Gerhauser, H., Kiel, J.H.A., Ptasinski, K.J., 2011. Biomass upgrading by torrefaction for the production of biofuels: a review. Biomass Bioenergy 35 (9), 3748-3762.

Stuart, T.E., Hoang, H., Hybels, R.C., 1999. Interorganizational endorsements and the performance of entrepreneurial ventures. Adm. Sci. Q. 44 (2), 315-349.

Thompson, N.A., Kiefer, K., York, J.G., 2011. Distinctions not dichotomies: exploring social, sustainable, and environmental entrepreneurship. In: Social and Sustainable Entrepreneurship (Advances in Entrepreneurship, Firm Emergence and Growth, vol. 13. Emerald Books, Bingley, UK, pp. 201-229.

Ulmanen, J.H., Verbong, G.P.J., Raven, R.P.J.M., 2009. Biofuel developments in Sweden and the Netherlands. Renew. Sustain. Energy Rev. 13 (6-7), 1406-1417. http://dx.doi.org/10.1016/j.rser.2008.10.001.

UNDP, 2007. Human Development Report 2007/2008. Human Development, pp. 229-232. ISBN 978-0-230-54704-9.

Ventresca, M.J., Mohr, L.B., 2002. Archival methods in organization studies. In Baum, J.A.C. (Ed.), Companion to Organizations. Blackwell Publishers Ltd, Oxford.

Verbong, G., Geels, F., 2007. The ongoing energy transition: lessons from a sociotechnical, multi-level analysis of the Dutch electricity system (1960-2004). Energy Policy 35 (2), 1025-1037.

Wickrama, K.A.S., Mulford, C.L., 1996. Political democracy, economic development, disarticulation, and social wellbeing in developing countries. Sociol. Q. 37 (3), 375-390. 
Wijen, F., Ansari, S., 2007. Overcoming inaction through collective institutional entrepreneurship: insights from regime theory. Organ. Stud. 28 (7), 1079-1100. http://dx.doi.org/10.1177/0170840607078115.

Woolthuis, R.K., Hooimeijer, F., Bossink, B., Mulder, G., Brouwer, J., 2013. Institutional entrepreneurship in sustainable urban development: Dutch successes as inspiration for transformation. J. Clean. Prod. 50, 91-100.
Young, W., Tilley, F., 2006. Can businesses move beyond efficiency? the shift toward effectiveness and equity in the corporate sustainability debate. Bus. Strategy Environ. 15 (6), 402-415.

Zilber, T.B., 2007. Stories and the discursive dynamics of institutional entrepreneurship: the case of Israeli high-tech after the bubble. Organ. Stud. 28 (7), 1035-1054. http://dx.doi.org/10.1177/0170840607078113.

Please cite this article in press as: Thompson, N.A., et al., How sustainable entrepreneurs engage in institutional change: insights from biomass torrefaction in the Netherlands, Journal of Cleaner Production (2014), http://dx.doi.org/10.1016/j.jclepro.2014.08.011 